\title{
Penanggulangan Bentrok Massa Akibat Konflik Pertanahan oleh Satuan Brimob Polda Sumatera Utara
}

\section{Mass Bentrok Management Due to Land Conflict by Brimob Unit of North Sumatera Polda}

\author{
Arke Furman Ambat*, Alpi Sahari \& Surya Perdana
}

Program Magister Ilmu Hukum, Universitas Muhammadiyah Sumatera Utara, Indonesia

Diterima: Juni 2020; Disetujui: Agustus 2020; Dipublish: Agustus 2020

* Email: arkeambat54@gmail.com

\begin{abstract}
Abstrak
Penanggulangan bentrok massa akibat konflik pertanahan yang dilakukan oleh Satuan Brimob Polda Sumatera Utara tidak akan efektif tanpa adanya dukungan dari masyarakat. Salah satu langkah efektif untuk mengantisipasi kerusuhan massa yang timbul dari permasalahan tanah sebagai gangguan Kamtibmas berkadar tinggi adalah mengimplementasikan sinergi polisional Patroli Kamandahan yang dilakukan oleh Satbrimob Polda Sumut terlebih dahulu mengaplikasikan pemetaan daerah rawan konflik pertanahan sebagai konflik yang timbul dari konflik sumber daya alam yang berpotensi terjadinya kerusuhan massa. Penelitian ini menggunakan penelitian hukum normatif, bersifat deskriptif analisis. Penanggulangan bentrok massa akibat konflik pertanahan yang dilakukan oleh Satuan Brimob Polda Sumatera Utara tidak akan efektif tanpa adanya dukungan dari masyarakat. Hambatan Satuan Brimob Polda Sumut dalam penanggulangan bentrok massa akibat konflik pertanahan yakni keterbatasan jumlah personel secara kuantitas yang ada dan secara kualitas belum berjalan secara optimal sehingga berdampak pada penilaian masyarakat dalam penanganan kerusuhan massa akibat konflik horizontal yang timbul dari permasalahan tanah meliputi Knowledge, Skill, Attitude. Upaya yang dilakukan oleh Satuan Brimob Polda Sumatera Utara adalah menerapkan manajerial metode Patroli Kamandahan dalam mengantisipasi bentrok massa akibat konflik pertanahan yang meliputi perencanaan, pengorganisasian, pelaksanaan, pengawasan dan pengendalian dinilai masih kurang optimal.
\end{abstract}

Kata Kunci: Penaggulangan, Bentrok Massa, Pertanahan

\begin{abstract}
The handling of mass clashes due to land conflicts carried out by the North Sumatra Regional Police Mobile Brigade Unit will not be effective without the support of the community. One effective step to anticipate mass riots arising from land problems as high-level Kamtibmas disturbance is to implement the polemical synergy of the Kamandahan Patrol conducted by the North Sumatra Police Mobile Brigade first applying the mapping of land conflict-prone areas as conflicts arising from natural resource conflicts that have the potential to cause mass riots. This research uses normative legal research, descriptive analysis. The handling of mass clashes due to land conflicts carried out by the North Sumatra Regional Police Mobile Brigade Unit will not be effective without the support of the community. The obstacle of the North Sumatra Regional Police Mobile Brigade in overcoming mass clashes due to land conflicts is the limited number of personnel in quantity and quality that has not been running optimally so that it has an impact on community assessments in handling mass riots due to horizontal conflicts arising from land issues including Knowledge, Skill, Attitude. Efforts made by the North Sumatra Regional Police Mobile Brigade were to apply the Kamandahan Patrol managerial method in anticipating mass clashes caused by land conflicts which included planning, organizing, implementing, monitoring and controlling were considered to be less than optimal.
\end{abstract}

Keywords: Tackling, Mass Clashes, Land

How to Cite: Ambat, A.F., Sahari, A. \& Perdana, S. (2020). Penanggulangan Bentrok Massa Akibat Konflik Pertanahan Oleh Satuan Brimob Polda Sumatera Utara. Journal of Education, Humaniora and Social Sciences (JEHSS). 3(1): 70-77. 


\section{PENDAHULUAN}

Kondisi lingkungan strategis yang didasarkan pada geografi, demografi, sumber daya alam, idiologi, politik, ekonomi, sosial budaya, pertahanan dan keamanan saat ini yang terjadi di Sumatera Utara sangat berpengaruh terhadap situasi Kamtibmas yang kondusif dengan meningkatnya kemungkinan terjadinya kontijensi antara lain terjadinya kerusuhan massa yang dikategorikan sebagai gangguan kamtibmas berkadar tinggi. Hal ini harus ditanggulangi dengan sasaran Kamtibmas tetap terpelihara sebagaimana dimaksud dalam Inpres No. 2 Tahun 2013 tentang Penanganan Gangguan Keamanan dalam Negeri yakni dengan pola penanganan konflik untuk mengantisipasi kerusuhan massa sebagaimana dimaksud dalam Undang-Undang RI No.7 Tahun 2012 tentang Penanganan Konflik Sosial.

Timbulnya kerusuhan massa dapat disebabkan oleh beberapa faktor yang diidentifikasi sebagai Sociocultural Animosity dan Social Disorder/ Chaos yang melahirkan intra society conflik misalnya kerusuhan massa yang disebabkan oleh faktor ketidakadilan masalah penyelesaian atas sengketa tanah yang timbul menyangkut penggunaan, penguasaan dan kepemilikan tanah yang menimbulkan konflik.

Masalah yang menyangkut tentang tanah merupakan permasalahan yang paling kompleks dan penyelesaiannya cukup rumit. Selain membutuhkan waktu yang lama dalam upaya penyelesaian permasalahnya, juga terlalu banyak melibatkan pihak-pihak yang mempunyai kepentingan didalam permasalahan tersebut. Masalah pertanahan hampir terjadi diseluruh Indonesia, tanpa terkecuali di Medan Provinsi Sumatera Utara. Di Medan terdapat lahan PTPN II yang karena kebutuhan masyarakat maka pemerintah memilih tidak memperpanjang HGU (Hak Guna Usaha) dengan tujuan untuk kepentingan masyarakat. Pemerintah menggangap bahwa rakyat lebih membutuhkan lahan tersebut guna memenuhi kebutuhan hidup dan mensejahterakan seluruh masyarakat.

Lahan PT. Perkebunan Nusantara II yang berada di Sumatera Utara berasal dari konsesi tanah NV. Van Deli Maatschappiy yang mulai diusahai pada tahun 1870 seluas 250.000 ha yang terbentang dari Sungai ular di Kabupaten Deli Serdang sampai ke Sei Wampu di kabupaten langkat (bumn.go.id). Pada tahun 2002 melalui SK BPN Pusat No, 42, 43, dan 44 / HGU/ BPN/2002 tanggal 29 Nopember 2002, Pemerintah tidak mengeluarkan lagi perpanjangan permohonan HGU PTPN II seluas 5.873,068 ha karena adanya tuntutan-tuntutan masyarakat dengan dasar SKPT-SL dan KTPPT (bumn.go.id). Khusus mengenai lahan seluas 5.873 ha yang sudah tidak di pepanjang HGU nya (Eks HGU) sesuai dengan SK BPN No.42,43 dan 44/HGU/BPN/2002, jelas disebutkan bahwa tanah-tanah perkebunan yang tidak di perpanjang tersebut akan menjadi tanah yang dikuasai langsung oleh negara dan menyerahkan pengaturan/penguasaan, pemilikan, pemampaatan dan penggunaan tanah tersebut kepada Gubernur Propinsi Sumatra Utara dan selanjutnya di proses sesuai ketentuan dan perundang-undangan yang berlaku setelah memperoleh ijin pelepasan aset dari Menteri yang berwenang dalam hal ini Menteri BUMN RI (bumn.go.id).

Permasalahan-permasaalahan lain yang menimbulkan konflik pertanahan atas lahan eks HGU PTPN II (Panduan Pertanahan Eks HGU PTPN II) ialah : a. area HGU yang diperpanjang dan telah terbit sertifikatnya seluas 11,842,09 Ha dan telah digarap masyarakat; b. arel belum terbit sertifikat HGU seluas 2.915,23 Ha; c. areal divestasi dan pinjam pakai; d. HGU yang tidak diperpanjang. Pengelolaan lahan eks HGU oleh pemerintah yang tidak sesuai dengan ketentuan tersebut menimbulkan banyak masalah yang berujung pada timbulnya suatu tindak pidana sehingga melibatkan peran Polri. Didalam pasal 2 Undang-Undang Nomor 2 tahun 2002 disebutkan bahwa fungsi kepolisian adalah salah satu fungsi pemerintahan negara di bidang pemeliharaan keamanan dan ketertiban masyarakat, penegakan hukum, perlindungan, pengayoman dan pelayanan kepada masyarakat.

Brimob adalah unsur bantuan taktis kepolisian yang sengaja didesain secara khusus untuk dapat melakukan manuver dengan daya gerak tinggi dan digunakan secara efektif dan efisien untuk penanggulangan gangguan Kamtibmas berintensitas tinggi. Atas dasar ini peran Brimob diarahkan menjadi unsur kekuatan operasional yang mampu membantu kepolisian kewilayahan dalam rangka penanggulangan gangguan Kamtibmas berintensitas tinggi guna terwujudkan tertib hukum dan ketenteraman masyarakat. 
Dalam operasional kepolisian peran Brimob dapat didayagunakan untuk membantu, melengkapi, memperkuat, melindungi dan menggantikan kegiatan operasional khusus yang dilakukan oleh satuan kewilayahan. Dalam melaksanakan operasional khusus untuk mengantisipasi gangguan Kamtibmas berkadar tinggi berupa kerusuhan massa yang timbul dari permasahan tanah agar tidak mengarah pada gangguan nyata maka diperlukan pengotimalan sinergi polisional patroli Kamandahan Sat Brimob. Adapun program patroli Kamandahan sebagaimana ditegaskan dalam Surat Telegram Kakorbrimob Polri Nomor: STR/49/XI/ 2012 diarahkan untuk mengembangkan potensi dan kekuatan dalam menangkal, mencegah dan menanggulangi segala bentuk pelanggaran hukum dan bentuk-bentuk gangguan lainnya yang dapat meresahkan masyarakat dengan sasaran perioritas untuk dilaksanakan yang dilakukan secara profesional dan proporsional untuk terwujudnya daya cegah dan daya tangkal terhadap gangguan Kamtibmas yang terjadi melalui program perubahan pola layanan Polri dalam penanggulangan kamtibmas yang secara intensif dan berdasarkan standart cout dengan mensinergikan kesatuan kewilayah. Hal ini tentunya akan meningkatkan kepercayaan masyarakat terhadap institusi Polri sehingga rasa aman, tertib dan tentram akan terwujud ditengah-tengah masyarakat. Di samping itu fungsi pembinaan masyarakat, diarahkan dalam rangka terciptanya situasi dan kondisi Kamtibmas yang kondusif.

\section{METODE PENELITIAN}

Spesifikasi penelitian ini adalah penelitian hukum normatif dan analisis kualitatif dengan sumber penelitian study kepustakaan/studi dokumen. Penelitian ini bersifat deskriptif analisis. Jenis data dalam penelitian ini berupa data sekunder yaitu dilakukan dengan cara studi pustaka (library research) atau penelusuran literatur di perpustakaan terhadap bahan-bahan hukum tertulis yang relevan, yang didukung dengan wawancara dengan personil di Satuan Brimob di Kepolisian Daerah Sumatera Utara. Literatur diperoleh melalu membaca referensi, melihat, mendengar seminar, pertemuan-pertemuan ilmiah, serta mendownload melalui internet. Wawancara dilakukan di Satuan Brimob Kepolisian Daerah Sumatera Utara.

\section{HASIL DAN PEMBAHASAN \\ Hambatan Satuan Brimob Polda Sumut Dalam Penanggulangan Bentrok Massa Akibat Konflik Pertanahan}

Polri sebagai komponen utama pemeliharaan keamanan dalam negeri sebagaimana diamanahkan Undang-Undang Nomor 2 Tahun 2002 tentang Polri yang dalam pelaksanaan tugas sebagai penegak hukum, tentunya dalam penanggulangan konflik pertanahan tentunya sangat bersentuhan dengan instansi terkait antara lain Pemerintah Daerah dan BPN. Pelibatan instansi ini dalam perkembangannya sering menghadapi berbagai kendala dan masalah. Kendala-kendala yang dihadapi misalnya terkait masalah kewenangan penyelesaian permasalahan tanah eks HGU PTPN II dengan dasar mempunyai tugas dan tanggung jawab sendiri-sendiri, akan tetapi dalam fakta di lapangan masing terjadi sengketa kewenangan penanganan permasalahan eks HGU PTPN II. Hal ini disebabkan berbagai hal baik terkait dasar hukumnya (legal standing) maupun substansi penyelesaian permasalahan HGU PTPN II yang tidak diperpanjang lagi.

Polri sebagai garda terdepan dalam menjaga keamanan dan ketertiban masyarakat terkait pelaksanaan penegakkan hukum (polisionil agency) yang timbul dari konflik pertanahan sering kali berbenturan dengan substansi hukum dan kewenangan instansi-instansi dalam penentuan status tanah eks HGU PTPN II, misalnya terdapat sebuah laporan dari masyarakat terkait penguasaan fisik lahan eks HGU PTPN II. Kemudian informasi tersebut diteruskan ke beberapa instansi antara lain BPN, BUMN dan Pemerintah Daerah. Konflik kewenangan antar intansi ini mengakibatkan penyidik Polri kesulitan untuk memproses tindak pidana menyangkut penguasaan fisik lahan eks HGU PTPN II, menurut Lufsiana konflik kewenangan adalah masing-masing instansi berwenang dalam menanganai permasalahan eks HGU PTPN II dan berjalan sendiri-sendiri tanpa adanya keterpaduan sistem dalam pelaksanaannya, artinya sama-sama berwenang tanpa adanya pembagian kewenangan secara tegas dan jelas tanpa adanya mekanisme kerja yang pasti (Lufsiana, 2008). 
Vol 3, No. 1, Agustus 2020: 70 -77

Peran Polri melalui pendekatan penal policy (Sahari, 2009) sebagai bahagian dari penanggulangan tindak pidana diartikan sebagai tindakan refresif melalui penegakan hukum pidana sebagai usaha untuk mengendalikan kejahatan agar berada dalam batas-batas toleransi (Mulyadi, 1998) tentunya tidak dapat dipisahkan dari hakekat ancaman terjadinya tindak pidana yang bersumber dari konflik pertanahan. Menurut pendapat Barda Nawawi Arief upaya penanggulangan tindak pidana dapat dilakukan dengan menempuh 3 (tiga) elemen pokok, yakni penerapan hukum pidana (criminal application), pencegahan tanpa pidana (prevention without punishment), dan mempengaruhi pandangan masyarakat mengenai kejahatan dan pemidanaan melalui media masa (influencing views of society on crime), (Arief, 2002). Jenis kewenangan penanggulangan konflik pertanahan lebih cenderung pada penerapan hukum pidana (penal policy) yang dilakukan oleh Polri khususnya Polresta Mesan. Ruang lingkup kebijakan hukum pidana sesungguhnya meliputi masalah yang cukup luas, yaitu meliputi evaluasi terhadap substansi hukum pidana yang berlaku saat ini untuk pembaharuan subtansi hukum pidana di masa mendatang dan bagaimana penerapan hukum pidana ini melalui komponen sistem peradilan pidana (Mulyadi, 2019).

\section{Hambatan sumber daya Satuan Brimob Polda Sumatera Utara sangat beroengaruh terhadap faktor-faktor yang mempengaruhi penaggulangan kerusuhan massa akibat pertanahan}

Faktor Internal, Kekuatan (Strenghts) adalah kemampuan internal yang positif dan situasi yang memungkinkan organisasi memiliki keuntungan strategis dalam mencapai tujuan (Rangkuti, 2006). Analisis kekuatan untuk impelentasi sinergi polisional anisipasi terjadi kerusuhan masa akibat kinflik pertanahan adalah sebagai berikut: a. Komitmen Kakorbrimob untuk menjaga stabilitas Kamtibmas akibat konflik yang timbul di tengah-tengah masyarakat melalui Surat Telegram Kakorbrimob Polri No. STR/49XI/2012. b. Kebijakan dan komitmen yang tinggi dari pimpinan Polri untuk selalui bersinergi dengam setiap unsur masyarakat dapat memperkuat motivasi sinergi polisional Patroli Kamandahan di kewilayahan untuk menciptakan kondisi Kambtimas yang mantab. c. Reformasi Birokrasi Polri dan akuntabilitas kinerja Polri menjadikan setiap kegiatan Polri semakin dapat dipertanggungjawabkan sesuai tupoksinya. d. Adanya disiplin dan loyalitas setiap anggota Satbrimob Polda Sumut dalam melaksanakan tugas sebagai salah satu faktor utama dalam mendukung keberhasilan tugas.

Kelemahan (weaknesses) ialah ketidakmampuan internal dalam organisasi yang menyebabkan organisasi tidak dapat mencapai tujuan (Freddy Rangkuti. 2006:14), untuk implementasi sinergi polisional antisipasi terjadinya kerusuhan massa akibat konflik pertanahan adalah, sebagai berikut: a. terbatasnya sumber daya personel bataliyon jajaran Satbrimob Polda Sumut baik secara kualitas maupun kuantitas khusunya personel yang bertugas untuk cipta kondisi dengan mengedepankan fungsi Binkamtibnas pada daerah-daerah rawan konflik; b. Belum adanya anggaran serta sarana dan prasarana penunjang pelaksanakan kegiatan Patroli Kamandahan untuk Satbrimob Polda Sumut khususnya di jajaran Batalyon Satbrimoob Polda Sumut; c. Belum adanya Buku Pedoman Pelaksanaan, Petunjuk Lapangan, Petunjuk Teknik serta Prosedur tetap dalam melaksanakan kegiatan Patroli Keamndahan; d. Masih lemahnya koordinasi dan komunikasi dengan Satuan Kewilayahan sehinnga terkesan bekerja sendiri-sendiri yang berakibat kurang efektifnya dalam penanganan gangguan Kamtibmas berkadar tinggi.

Faktor Eksetnal, Peluang (opportunities) adalah merupakan faktor-faktor eksernal dan situasi di luar organisasi yang membantu organisasi dan mencapai tujuan (Rangkuti, 2006). Implementasi sinergi polisional antisipasi terjadinya kerusuhan masa akibat konflik pertanahan ialah adanya dukungan dan kepedulian dari pemerintah daerah untuk menanggulangi konflik sosial yang terjadi ditengah-tengah masyarakat. Adanya dukungan dari masyarakat dalam penanggulangan gangguan Kamtibmas berkadar tinggi terutama untuk mengantisipasi kerusuhan masa yang timbul dari permasalahan tanah (sumber daya alam). Akses informasi yang terbuka unutk meliputi setiap proses kegiatan kepolisian yang dapat berimpllikasi pada etos kerja penyelanggara patroli kepolisisan khususnya Patroli Kamandahan. Hal ini dapat dijadikan Polri sebagai kontrol sosial, sekaligus pemicu dan pemacu kinerja di lapangan dalam cipta kondisi. 
Adanya kontrol sosial dari LSM maupun media massa terhadap kepolisian khusunya dalam penaganan konflik yang berdampak pada gangguan Kamtibmas berkadar tinggi sehingga memberikan dorongan moril kepada personil Polri.

Ancaman (threats) merupakan faktor-faktor eksternal yang menyebabkan oranisasi tidak dapat mencapai tujuan (Rangkuti, 2006), untuk implementasi sinergi polisional antisipasi terjadinya kerusuhan massa akibat konflik pertanahan adalah Makin meningkatnya potensi konflik di kewilayahan yang mengarah pada kerusuhan massa, akibat belum adanya pemecahan masalah pertanahan secara solutif dilakukan oleh stakeholders (pemerintah daerah dan pihak yang mempunyai otoritas di bidang perkebunan). Masih rendahnya kesaadaran hukum masyarakat sehingga rentan dengan gesekan yang memicu konflik soisal Hakim, dkk., 2013; Prakoso, dkk., 2016; Silalahi, 2018).

Masih terdapatnya penilaian negatif serta sikap apriori, apatisme, pesimisme dan bahkan sinisme dari sebagian kecil anggota masyarakat terhadap Polri sebagai dampak meningkatnya daya kritis masyarakat yang cenderung digunakan secara salah dengan mencari-cari kesalahan yang dilakukan Polri dalam pelaksanaan tugasnya. Adanya ego sektoral yang masih kuat dari instansi yang akan melakukan kerja sama karena masing-masing instansi merasa mempunyai kewenangan di lingkungan kerjanya.

\section{Upaya Satuan Brimob Polda Sumut Dalam Penaggulangan Bentrok Massa Akibat Konflik Pertanahan}

Menyikapi potensi konflik pertanahan yang terjadi dan berpotensi terjadinya kerusuhan massa, perlu dirumuskan langkah-langkah strategis untuk mengantisipasinya melalui percepatan dan penguatan patnership dengan lintas sektoral (infra struktur maupun supra struktur), antara lain Membangun hubungan kemitraan dengan berbagai potensi lintas sektoral (formal maupun informal) termasuk kelembagaan dalam masyarakat, termasuk tokoh-tokoh masyarakat, tokoh agama maupun tokoh adat, sebagai salah satu upaya dalam rangka mencegah terjadinya konflik pertanahan (Komandan Batalyon A Satuan Brimom Polda Sumut;2019).

Satuan Brimob Polda Sumut dan lintas sektoral bertindak selaku juru penerang tau sumber informasi tentang hasil identifikasi konflik, untuk dijelaskan kepada masyarakat mengetahui secara benar , tentang apa yang terjadi, sebab-sebab konflik maupun akibat dari konflik tersebut. Sehingga dapat mengurangi emosional primordial dalam menghadapi konflik pertanahan (Komandan Sub Batalyon A Satuan Brimob Polda Sumut). Satuan Brimob Polda Sumut dan lintas sektoral berperan sebagai motivator dalam penyelesaian konflik pertanahan dengan cara mendorong dan mendinamisir masyarakat untuk mencapai dan melaksanakan cara-cara penyelesaian sesuai dengan aturan-aturan hukum yang berlaku (positivisme).

Satuan Brimob Polda Sumut sebagai mitra dalam penyelesaian konflik, harus bersikap netral dalam membantu dan melayani semua pihak yang berkonflik, serta memfasilitasi kepentingankepentingan semua pihak untuk proses penyelesaian konflik pertanahan. Satuan Brimob Polda Sumut berperan sebagai pelindung, pengayom dan pelayan masyarakat dengan senantiasa menciptakan suasana aman dan tentram pada lingkungan dan Polri berperan sebagai penegak hukum melalui upaya penegakan hukum dengan mengedepankan nilai-nilai hukum yang tumbuh pada lingkungan masyarakat yang bersangkutan seperti hukum adat, sedangkan penegakan hukum menurut hukum nasional dilaksanakan apabila proses penyelesaian konflik pertanahan oleh masyarakat tidak mampu menyelesaikan permasalahan.

Bersama-sama membentuk lembaga penanganan sengketa pertanahan dengan sasaran kegiatan melakukan analisis menyangkut penanggulangan konflik-konflik yang akan akan muncul dari permasalahan pertanahan berdasarkan pada tingkatan-tingkatan (Sibarani, 2019; Gunanti, dkk., 2012; Hasibuan, dkk., 2013). Di samping itu dilakukan monitoring dan menilai setiap gejala yang dapat berkembang dalam bentuk gangguan keamanan, sehingga mempermudah dalam melakukan langkah-langkah antisipatif. Membuat SOP penanganan permasalahan tanah yang memicu konflik horizontal yang didahului dengan meminta masukan informasi atau bahan keterangan yang dimiliki oleh anggota SKPD terhadap permasalahan yang diangkat untuk dijadikan bahan analisa dan evaluasi lanjut dalam cara bertindak di dalam SOP. 
Vol 3, No. 1, Agustus 2020: 70 -77

Meminta saran pendapat dari antar lintas dan lembaga Negara yang tidak tunduk pada otonomi daerah sekaligus usulan pemecahan masalah yang bisa diambil terhadap penanggulangan konflik pertanahan. Lembaga penanganan sengketa tanah memberikan pandangan secara hukum kepada kementerian terkait terhadap langkah yang akan, sedang dan sudah diambil terhadap penanganan permasalahan tanah. Deteksi dini (early warning system), yaitu; a. Pra kerusuhan/konflik. Pada pra kerusuhan perlu dilakukan langkah-langkah mengidentifisir kondisikondisi yang mendukung terjadinya konflik meliputi: isu-isu yang memperkuat solidaritas sosial dan penumpukan massa dari beberapa kelompok penggarap lahan yang mengarah pada penguasaan tanah secara paksa. $a$. fase pematangan kerusuhan/konflik. Pada fase pematangan kerusuhan/konflik, perlu dilakukan upaya mengidentifisir provokator yang mulai bekerja untuk mematangkan kerusuhan dan menyebarkan isu-isu serta tindakan yang mendukung kerusuhan. $c$. Kerusuhan/konflik. Pada tahap terjadi konflik/kerusuhan, maka perlu di identifisir tindakan agresif kelompok-kelompok penggarap dan penyebaran konflik atau kerusuhan. $d$. Pasca kerusuhan/konflik. Pada pasca kerusuhan, perlu dilakukan identifikasi terhadap korban-korban baik fisik maupun non fisik, pengungsian dan kerusakan tatanan sosial serta bangunan dan tempat tinggal, maupun trauma korban dan rasa takut serta rasa aman.

\section{Penaggulangan secara preventif dengan cara, segera melakukan koordinasi dengan aparat pemerintah dan aparat keamanan untuk memperjelas situasi}

Mengumpulkan informasi berkaitan dengan permasalahan tanah yang terjadi sehingga menimbulkan konflik horizontal, kemudian didialogkan untuk mengetahui bagaimana permasalahan yang sebenarnya dan selanjutnya informasi tersebut disampaikan kepada masyarakat melalui media massa, sedangkan pemerintah daerah harus berperan sebagai mediator antar pihak yang berkonflik.

Aparat keamanan segera melakukan langkah-langkah Blokade dan mengamankan daerahdaerah rawan konflik dan penyebarannya serta koordinasi antar pasukan maupun koordinasi dengan pemerintah dan masyarakat serta mengidentifikasi dan mengamankan pihak-pihak yang dianggap sebagai provokator. Bila ditemukan bukti-bukti yang kuat, maka langsung dilakukan penangkapan pihak-pihak yang dianggap sebagai provokator dan harus ada pertanggung jawaban dari pihak aparat bila gagal dalam menangani konflik.

Dalam kaitan terjadi konflik/kerusuhan, maka para pemimpin atau tokoh masyarakat, tokoh adat segera melakukan kontak atau dialog untuk mencari akar permasalahan dan menghentikan konflik. Serta masing-masing kelompok masyarakat diupayakan tidak melakukan penumpukan massa.

Pemerintah harus segera melakukan koordinasi secara proaktif antar sesama aparat pemerintah, maupun dengan masyarakat dalam rangka menangkal isu-isu yang berkembang dan mencegah terjadinya konflik serta melokalisir isu maupun tindakan yang mengarah pada agresifitas massa.

Aparat keamanan segera membubarkan, memecah massa ke daerah-daerah yang aman sehingga mampu dikendalikan dan melakukan penangkapan terhadap provokator maupun massa penggerak kerusuhan serta melakukan pengamanan wilayah-wilayah lain yang diperkirakan akan terkena konflik. Disamping itu melakukan langkah-langkah melokalisir pusat-pusat ketegangan konflik dalam rangka mengidentifisir dan mengamankan pihak-pihak yang dianggap sebagai provokator serta menambah jumlah aparat keamanan pada daerah-daerah yang dianggap rawan konflik agar tidak meluas ketempat lain.

Penanggulangan konflik dalam hal penegakan hukum dapat diakukan dengan Melaksanakan kegiatan penyelidikan dan penyidikan terhadap setiap kasus pelanggaran hukum yang terjadi sesuai dengan ketentuan/prosedur hukum yang berlaku serta senantiasa menjunjung tinggi HAM. Penegakan hukum dilakukan dengan berorientasi kepada sistem hukum nasional dalam menyelesaikan tindak pidana yang terjadi. Solusi yang dikemukakan dalam rangka mengatasi masalah penegakan hukum dalam penanggulangan konflik harus mendasri pada tiga konsep yang saling berhubungan, yakni (Muladi, 2004; 121) Pertama, konsep penegakan hukum yang bersifat total (total enforcement concept), yang menuntut agar semua nilai yang ada di belakang norma

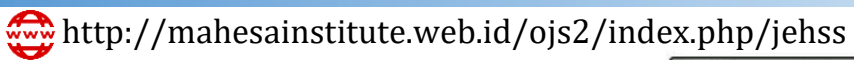
(4) mahesainstitut@gmail.com 75 
hukum tersebut ditegakkan tanpa kecuali. Kedua, konsep penegakan hukum yang bersifat penuh (full enforcement concept), yang menyadari bahwa konsep total perlu dibatasi dengan hukum acara dan sebagainya demi perlindungan kepentingan individual. Ketiga, konsep penegakan hukum yang bersifat aktual (actual enforcement concept), yang muncul setelah diyakini adanya diskresi dalam penegakkan hukum karena keterbatasan-keterbatasan, baik yang berkaitan dengan sarana-prasarana, kualitas sumber daya manusia, kualitas perundang-undangannya, dan miskinnya partisipasi masyarakat.

Melakukan penangkapan terhadap para pelaku tindakan anarkhis pada saat kerusuhan massa dan terhadap para pimpinan kelompok yang menggunakan massa serta para provokatorprovokator yang membiayai terjadinya kerusuhan massa yang bersifat anarkhis, baik pimpinannya maupun anggotanya kemudian melakukan langkah-langkah penyidikan untuk diajukan ke Penuntut Umum.

Selaras dengan tujuan dan sasaran yang akan dicapai melalui peningkatan kemampuan Satuan Brimob Polda Sumut serta mengacu pada permasalahan-permasalahan yang terjadi di lapangan selama ini untuk menanggulangi bentrok massa akibat konflik pertanahan, maka strategi Satuan Brimob Polda Sumut adalah mengimplementasikan sinergi polisional Patroli Kamandahan yang akan ditingkatkan dengan cara, sasaran jangka pendek, pada aspek dukungan sumber daya Batalyon jajaran Satbrimob Polda Sumut diarahkan untuk meningkatkan kuantitas dan kualitas sumber daya manusia secara bertahap disertai dengan memadainya dukungan anggaran, sarana dan prasarana serta optimalnya sistem dan metode. Sedangkan pada aspek sinergitas Batalyon jajaran Satbrimob Polda Sumut dengan Satuan Kewilayahan dan instansi terkait dalam menunjang implementasi sinergi polisional Patroli Kamandahan dilaksanakan sosialisasi program antisipasi terjadinya kerusuhan massa akibat konflik pertanahan kepada seluruh masyarakat. Kemudian pada aspek metode Patroli Kamandahan dalam mengantisipasi kerusuhan massa akibat konflik pertanahan diterapkan pada tahap perencanaan.

Sasaran jangka sedang, melakukan cipta kondisi pada daerah rawan konflik pertanahan. Pada aspek sinergitas Batalyon jajaran Satbrimob Polda Sumut dengan Satuan Kewilayahan dan instansi terkait dalam menunjang implementasi sinergi polisional Patroli Kamandahan dilaksanakan pertemuan secara rutin dan berkala serta merumuskan program kegiatan terpadu. Pada aspek metode Patroli Kamandahan dalam mengantisipasi kerusuhan massa akibat konflik pertanahan diterapkan pada tahap pengorganisasian dan pelaksanaan.

Jangka panjang, diarahkan untuk terimplementasinya sinergi polisional Patroli Kamandahan dengan Satuan Kewilayahan dan instansi terkait sebagai upaya antisipasi terhadap segala bentuk ancaman kontijensi yang berpengaruh pada gangguan Kamtibmas berkadar tinggi, terutama dalam mengantisipasi kerusuhan massa yang timbul dari permasalahan tanah (konflik sumber daya alam). Pada aspek sinergitas Batalyon jajaran Satbrimob Polda Sumut dengan Satuan Kewilayahan dan instansi terkait dalam menunjang implementasi sinergi polisional Patroli Kamandahan dilaksanakan upaya penggalangan terhadap tokoh yang berpengaruh di masyarakat dan kerjasama dalam hal kemitraan dimaksudkan sebagai upaya deteksi dini. Pada aspek metode Patroli Kamandahan dalam mengantisipasi kerusuhan massa akibat konflik pertanahan diterapkan pada tahap pengawasan dan pengendalian.

\section{SIMPULAN}

Berdasarkan uraian tersebut maka dapat diambil simpulan bahwa Hambatan Satuan Brimob Polda Sumut dalam penanggulangan bentrok massa akibat konflik pertanahan yakni keterbatasan jumlah personel secara kuantitas yang ada dan secara kualitas belum berjalan secara optimal sehingga berdampak pada penilaian masyarakat dalam penanganan kerusuhan massa akibat konflik horizontal yang timbul dari permasalahan tanah meliputi Knowledge, Skill, Attitude. Belum intensifnya sinergitas dengan instansi terkait antara lain pemerintah daerah kota Medan dan BPN Kota Medan. Kerjasama yang dilakukan masih bersifat parsial dan isidentil (pragmatig) dalam penyelesaian sengketa pertanahan. Upaya yang dilakukan oleh Satuan Brimob Polda Sumatera Utara adalah menerapkan manajerial metode Patroli Kamandahan dalam mengantisipasi bentrok 
massa akibat konflik pertanahan yang meliputi perencanaan, pengorganisasian, pelaksanaan, pengawasan dan pengendalian dinilai masih kurang optimal.

\section{DAFTAR PUSTAKA}

Arief, B.N. (2002). Masalah Penegakan Hukum dan Kebijakan Penanggulangan Kejahatan, PT. Citra Aditya Bakti, Bandung

Gunanti, B., Suhaidi, (2012), Peran Kepolisian Daerah Sumatera Utara dalam Penanggulangan Tindak Pidana Kehutanan di Wilayah Kabupaten Madina, Mercatoria, 5 (1): 104-115

Hakim, A., dan Tan K., (2013), Peranan Polri dalam Penanggulangan Tindak Pidana Pencurian oleh Anak (Studi di Wilayah Hukum Kepolisian Resort Kota Medan), Mercatoria, 6 (2): 145-175

Hasibuan, A.D., dan Ferry A.S., (2013), Faktor Penyebab Tidak Dilaksanakannya Putusan Pengadilan Tata Usaha Negara dan Upaya Penanggulangannya (Analisis Kasus Putusan PTUN Medan No: 17/G/2000/PTUN-MDN), Mercatoria, 6 (2): 133-144

http://www.bumn.go.id/ptpn2/berita/48/Sejarah.dan.Perkembangan.Lahan.PTPN.II

Lufsiana, (2008). Konflik Kewenangan Penegakan Hukum Perikanan, Cakrawala

Muladi, (2004). Demokratisasi, Hak Asasi Manusia, dan Reformasi Hukum, The Habibie Center, Jakarta.

Muladi. (1995). Kapita Selekta Sistem Peradilan Pidana. Universitas Diponegoro, Semarang

Mulyadi, (2008). Criminal Policy, Pendekatan Integral Penal Policy dan Non-Penal Policy dalam penanggulangan kejahatan kekerasan, Pustaka Bangsa Press, Medan,

Prakoso, B. Arifin.S, \& Mubarak, R (2016). Peranan Kantor Pengawasan Dan Pelayanan Bea Dan Cukai Belawan Dalam Penanggulangan Penyelundupan Satwa Dilindungi Jurnal Ilmiah Penegakan Hukum, 3 (2) 2016: 103-108

Rangkuti, F. (2006). Analisis SWOT: Tehnik Membedah Kasus Bisnis, PT Gramedia Pustaka Utama, Jakarta

Sibarani, A. Arifin, S. \& Siregar, T. (2019). Analisis Hukum Pidana Terhadap Penanggulangan Kejahatan Illegal Logging Di Provinsi Riau (Studi Kasus di Pengadilan Negeri Pekanbaru) ARBITER: Jurnal Ilmiah Magister Hukum, 1(1) 2019: 19-30.

Silalahi, D.H. (2018). Penanggulangan Tindak Pidana Penyalahgunaan Narkotika di SAT RES Narkoba Polres Tebing Tinggi, Jurnal Ilmiah Penegakan Hukum5, (2): 60- 67.

Undang-Undang Republik Indonesia Nomor 2 Tahun 2002 tentang Kepolisian Negara Republik Indonesia. 